\title{
Venetoclax Regimen
}

National Cancer Institute

\section{Source}

National Cancer Institute. Venetoclax Regimen. NCI Thesaurus. Code C160141.

A chemotherapy regimen consisting of venetoclax that may be used in the treatment of chronic lymphocytic leukemia (CLL)/small lymphocytic lymphoma (SLL). 